\title{
Warisan Kejayaan Madinah bagi Pengembangan Kajian Ilmu Sosial dan Politik
}

\section{Sidik Jatmika}

Jurusan IImu Hubungan Internasional, Fakultas IImu Sosial IImu Politik, Universitas Muhammadiyah Yogyakarta

Ringroad Barat Tamantirto, Kasihan, Bantul 55183

Email: sidikjatmika@umy.ac.id

\begin{abstract}
Besides giving ethic things, the glory of Madinah also gives some ideas, concept and perspective on social and political sciences for the future. What shows in the Muhammad prophet leadership in the Madinah period was given precious contribution on Khazanah social and political sciences which developing. Various of law, ethics, even recent ideas had historic roots in Madinah era.

Keywords: jihad, constitution, civilization, different opinion.

Abstrak

Selain mewariskan hal-hal yang bersifat etis, kejayaan Madinah juga mewariskan sejumlah gagasan, konsep serta perspektif dalam ilmu sosial dan ilmu politik di kemudian hari. Apa yang telah diperlihatkan dalam kepemimpinan Nabi Muhammad SAW dalam periode Madinah, memberi kontribusi yang berharga dalam khazanah ilmu sosial dan ilmu politik yang saat ini berkembang. Berbagai hukum, etika bahkan gagasan mutakhir, memiliki akar historisnya pada masa Madinah.

Kata kunci: jihad, konstitusi, peradaban, perbedaan pendapat
\end{abstract}

\section{PENDAHULUAN}

Michael H.Hart (Hart, 1997) dalam kajiannya telah menempatkan Rasulullah Muhammad SAW dalam urutan pertama di antara 100 tokoh yang paling berpengaruh dalam sejarah dunia. Sedangkan Datuk Anwar Ibrahim (Malaysia) dan Nurcholish Madjid (Indonesia) telah mengambil fakta sosial politik Madinah di bawah kepemimpinan Rasulullah SAW, sebagai prototipe masyarakat politik/sipil yang ideal (masyarakat Madani). Tulisan ini bermaksud untuk mengungkap lebih jauh beberapa hal yang telah diwariskan oleh masa kejayaan madinah terhadap pengembangan kajian ilmu sosial politik pada masamasa berikutnya.

\section{PEMBAHASAN}

Kemakmuran Madinah, Bagian Dari Jalur Sutera Madinah adalah nama sebuah kota, salah satu kota suci umat Islam di Tanah Haram di samping Makkah. Kota itu dikenal juga dengan nama yang lebih panjang Madinat al-Munawwarah (Kota Cahaya); dan Madinat al-Nabi (Kota Nabi). Kota itu tadinya disebut Yatsrib.

Sebelum lebih jauh menguraikan mengenai kejayaan Madinah; penulis merasa perlu untuk memberikan catatan mengenai istilah Madinat al Munawwarah (Kota Cahaya). Sebutan "Kota Cahaya" merupakan istilah idiom (perumpamaan) untuk menggambarkan bahwa hijrahnya Rasulullah ke Yastrib telah membawa perubahan terhadap kota tersebut dari situasi peradaban yang 'gelap' (jahlun, 
jahil, jahilliyah); menuju 'cahaya' (hidayah, munawwarah). Yang patut digarisbawahi bahwa sebutan situasi 'gelap' (jahilliyah), lebih berdimensi moralitas dan tauhid; dan bukannya dalam dimensi ekonomi dan kesenian. Saat Rasulullah hijrah itu, Yatsrib merupakan kota yang makmur karena alamnya yang relatif subur dan terletak di jalur perdagangan internasional (Jalur Sutera) yang terbentang dari Roma \& Venesia (Italia), Syam (Suriah); Petra (Yordania); Alexandria (Mesir); Yaman; India; Nusantara; hingga China (Hassan, 1997: 15-25).

Pada tahun 622 M, Nabi Muhammad s.a.w berhijrah ke kota itu bersama dengan 70 orang sahabatnya. Kedatangan Nabi dan sahabatnya membawa perubahan besar, baik di bidang politik, sosial, ekonomi maupun budaya. Madinah didiami oleh berbagai golongan suku bangsa Arab dan bangsa Yahudi yang menganut agama dan keyakinan yang berbeda. Corak masyarakatnya yang majemuk ini bertambah kompleks sejak sebagian penduduknya memeluk Islam dan setelah Nabi Muhammad bersama kaum muslim Makkah hijrah ke kota itu. Para ahli berbeda pendapat dalam merumuskan golongangolongan penduduk yang terdapat di Madinah pasca hijrah. Hasan Ibrahim Hasan menyebutnya empat golongan: Muhajirin, orang-orang Islam yang hijrah dari Makkah; Anshar, orang-orang Islam dari penduduk Madinah; kaum munafik dan musyrik; dan kaum Yahudi yang tinggal di Madinah (Hasan, 1979: 102).

Madjid Khadduri, (Khadduri, 1955: 209) George E. Kerk, (1949: 13) dan Ahmad A.Galwash, (1940: 64) hanya menyebut tiga golongan tanpa menyebut golongan munafik, yaitu Muhajirin, Anshar, dan Yahudi. A.G. Bouquet (Ahmad dalam Boquet, 1961: 268-2690), juga menyebut tiga golongan tanpa menyebut kaum Yahudi, yaitu Muhajirin, Anshar, dan Munafik. Sedangkan Muhammad Khalid hanya menggolongkan penduduk Madinah ke dalam dua golongan saja, yaitu kaum muslimin Muhajirin dan Anshar, dan kaum Yahudi (Khalid, 1955) Demikian juga 'Abd al-Muta'al al-Shu'adi mengelompokkannya ke dalam dua golongan. Tapi ia melihatnya dari segi kebangsaannya, yaitu bangsa arab yang terdiri dari kaum Muhajirin, Anshar, dan kaum munafik; dan bangsa Yahudi yang terdiri dari berbagai suku.

Al-Quran juga menyinggung tentang penduduk Madinah yang terdiri dari berbagai kelompok keyakinan. Dalam surat al-Taubat ayat 100 dan 117 disebut kaum Muhajirin dan Anshar, dan pada ayat 101 disebut dengan jelas adanya golongan munafik disekitar mereka. Sedangkan golongan Yahudi, Nasrani, dan Musyrik baik yang tinggal di Madinah maupun di sekitarnya disebut dalam surat al-Maidat ayat $82 .{ }^{1}$

Sekalipun mereka berbeda pendapat dalam mengkategorikan penduduk Madinah, namun cakupannya mengandung inti yang sama, yaitu bahwa penduduk kota itu bercorak heterogen atau majemuk. Kemajemukan tersebut dapat dilihat dari berbagai segi. Dilihat dari segi kebangsaan, penduduk Madinah terdiri dari bangsa Arab dan bangsa Yahudi, yang masing-masing terbagi ke dalam suku-suku. Dilihat dari asal daerah, mereka adalah orang-orang Arab Makkah, orang-orang Arab dan Yahudi Madinah. Dilihat dari struktur sosial dan kultur, mereka sama-sama menganut sistem kesukuan tapi berbeda dalam adat kebiasaan. Dilihat dari ekonomi, bangsa Yahudi adalah golongan ekonomi kuat yang menguasai pertanian, perdagangan dan keuangan, sedangkan kaum Arab adalah golongan ekonomi kelas dua. Dilihat dari segi agama dan keyakinan, mereka terdiri dari penganut agama yahudi, penganut agama kristen minoritas, penganut agama Islam, golongan munafik dan penganut paganisme(musyrik).

Dalam uraian diatas tampak bahwa heterogenitas penduduk Madinah adalah dalam hal etnis dan bangsa, asal daerah, ekonomi, agama dan keyakinan serta adat kebiasaan. Kondisi ini menyebabkan tiap golongan memiliki cara berpikir dan bertindak sendiri dalam mewujudkan kepentingannya sesuai dengan filosofi hidupnya yang dipengaruhi oleh keyakinan yang dianutnya, kulturnya dan tuntutan situasi. Ditambah pula manusia sebagai makhluk sosial dan makhluk politik mempunyai "dua sifat yang bertentangan satu sama lain; di satu pihak dia ingin kerjasama, di pihak lain dia cenderung untuk bersaing 
dengan sesama manusia” (Budiarjo, 1989: 32, Abi Rabi, 1970: 101-102, Al-Mawardi, 1950: 136, Khaldun: 41, Al-Ghazali, 1975: 1745) Faktor-faktor tersebut mengakibatkan mudahnya timbul konflik di antara mereka. Sebab, masyarakat yang terdiri dari berbagai golongan dan mempunyai perbedaan kepentingan yang tajam dalam bidang sosial, ekonomi, politik dan sebagainya cenderung ingin saling menghancurkan.

Nabi Muhammad tampaknya memahami benar bahwa masyarakat yang beliau hadapi adalah masyarakat majemuk yang masing-masing golongan bersikap bermusuhan terhadap golongan lain. Untuk itu, beliau melihat perlu adanya penataan dan pengendalian sosial untuk mengatur hubunganhubungan antar golongan dalam kehidupan sosial, ekonomi, politik, dan agama. Estimasi ini didasarkan pada langkah beliau setelah tiba di Madinah.

Langkah pertama, begitu beliau tiba di kota itu, adalah membangun masjid. Lembaga keagamaan dan sosial ini dari segi agama berfungsi sebagai tempat beribadah kepada Allah, dan dari segi sosial berfungsi sebagai tempat mempererat hubungan dan ikatan di antara anggota jamaah Islam (Syarif, 1972: 87). Langkah beliau yang kedua ialah menciptakan persaudaraan nyata dan efektif antara orang-orang Islam Makkah dan Madinah, yaitu setiap dua orang bersaudara karena llah. Persaudaraan ini dimaksudkan untuk mempererat persatuan di antara sesama kaum muslimin dan untuk menghilangkan permusuhan lama di kalangan mereka.

Jika langkah pertama dan kedua ditujukan khusus kepada konsolidasi umat Islam, maka langkah beliau berikutnya ditujukan kepada seluruh penduduk Madinah. Untuk itu beliau membuat perjanjian tertulis atau piagam yang menekankan pada persatuan yang erat di kalangan kaum muslimin dan kaum Yahudi, menjamin kebebasan beragama bagi semua golongan, menekankan kerjasama dan persamaan hak dan kewajiban semua golongan dalam kehidupan sosial politik dalam mewujudkan pertahanan dan perdamaian, dan menetapkan wewenang bagi Nabi untuk menengahi dan memutuskan segala perbedaan pendapat dan perselisihan.

Datangnya ayat-ayat al-Quran yang menyempurnakan konstitusi Madinah, maka warga negara-kota Madinah mulai hidup berdasarkan aturanaturan hukum dan moral. Dengan turunnya ayat 59 surat al Nisa' 4, maka warga masyarakat mulai memiliki orientasi dalam perilakunya, yaitu menyesuaikan diri dengan ajaran al-Quran, mengikuti tuntunan Rasulullah s.a.w. dan taat kepada pimpinan (yang oleh al-Quran disebut ulu al-amr-i). Dari sinilah mulai berkembang konsep negara ideal: Negara bukan semata-mata instrumen individu dalam memenuhi kepentingan mereka, tetapi sebuah pribadi yang berisikan cita-cita luhur. Negara seperti ini hanya bisa tegak jika didukung oleh suatu umat yang merupakan komunitas yang berakhlak.

Negara, dalam sejarah Islam, sebagaimana tercermin dalam al-Quran dan Sunnah Rasul, adalah sebuah negara-ideal, sekaligus negara-musyawarah yang berusaha mencerminkan dan menyelenggarakan berbagai kepentingan masyarakat yang berbeda. Sebagai negara-ideal, maka negara yang dicontohkan oleh negara-kota Madinah, adalah lembaga yang merupakan penubuhan cita-cita yang luhur, yaitu amanah, keadilan, kebajikan, dan amr bi al-ma'ruf wa nahy 'an almunkar. Namun dalam kenyataan, negara tidak dapat menghindarkan diri dari konflik dan perbedaan pendapat. Karena itu negara perlu menerapkan cara terbaik untuk mengatasi konflik dan perbedaan pendapat, yaitu doktrin ketaatan kepada ulu al-amr-i dan doktrin musyawarah bi al-ma'ruf.

Beberapa unsur yang terdapat dalam masyarakat Madinah

\section{Khalifah}

Penafsiran tentang konsep khalifah ini ternyata beragam. Karena kata khalifah dalam Al-Quran dan berbagai kata jadiannya, menimbulkan berbagai arti dan membuka penafsiran yang beragam. Para sarjana banyak mengacu pada konsep khalifah ini dalam mengembangkan teori dan sistem politik Islam. Tetapi, istilah khalifah tidak berdiri sendiri. Karena itu, dalam rangka mengembangkan teori dan sistem politik 
Islam, istilah ini perlu dikaitkan dengan konsepkonsep lain.

\section{Adil}

Pengertian adil, dalam budaya Indonesia, berasal dari ajaran Islam. Kata ini adalah serapan dari kata Arab 'adl. Dalam bahasa Inggris, kata ini diterjemahkan sebagai justice. Dalam Islam, keadilan pada akhirnya dipahami sebagai "keadilan Ilahi". Ada tiga nilai fundamental yang dinyatakan dalam al-Quran, yaitu tawhid atau pengesaan Allah, Islam, atau penyerahan dan ketundukan kepada Allah, dan keadilan, yaitu keyakinan bahwa segala perbuatan kita di dunia ini kelak akan dinilai Allah, Hakim Yang Maha Adil. Karena itu, kita harus bersikap dan bertindak adil.

Dengan demikian, keadilan dalam konteks alQuran, tidak lepas dari moralitas. Realisasi keadilan, pertama-tama berpedoman pada wahyu Ilahi. Keadilan itu sendiri bisa dipahami sebagai realisasi yang setia terhadap hukum-hukum Ilahi. Allah, sebagai Yang Maha Adil, memerintahkan manusia bersikap adil, baik terhadap diri sendiri maupun orang lain. Keadilan adalah sendi pergaulan sosial yang paling fundamental. Dengan nilai keadilan itulah sesungguhnya masyarakat tercipta. Jika keadilan dilanggar, maka sendi-sendi masyarakat akan goyah. Seorang yang melanggar keadilan, barangkali akan mendapat suatu keuntungan bagi dirinya sendiri. Tetapi dalam jangka panjang, ketidakadilan akan merugikan semua orang, termasuk yang melanggar keadilan.

\section{Syura}

Syura, sebenarnya adalah suatu forum, di mana setiap orang mempunyai kemungkinan untuk terlibat dalam urun rembug, tukar pikiran, membentuk pendapat dan memecahkan suatu persoalan bersama. Dalam situasi konkret, musyawarah bisa berbentuk "musyawarah anggota" dalam perkumpulan atau koperasi. Hasil musyawarah itu adalah program yang kemudian berstatus sebagai amanah. Dalam mempergunakan qiyas (analogi), maka lembaga syura dapat diwujudkan dalam berbagai situasi. Syura dalam perspektif penafsiran baru, dapat disebut sebagai metode partisipatoris. Kalau pada masa lalu, syura ditafsirkan sebagai lembaga demokrasi parlementer, maka dalam teori sosial sekarang ini, syura dapat dikembangkan sebagai lembaga demokrasi partisipatoris.

\section{Jihad}

Tidak sedikit buku, apalagi artikel, yang secara khusus membahas tentang istilah jihad dalam berbagai konteksnya. Sebagai contoh adalah buku kecil karangan Hasan al-Banna, pemimpin terkemuka gerakan ikhwan al-muslimin, di Mesir, yang berjudul Risalah Jihad. Buku ini cenderung mengartikan jihad sebagai perjuangan bersenjata dan kata jihad memang dipakai untuk membangkitkan semangat dan motivasi untuk berjuang dengan mempertaruhkan nyawa. Sehingga tulisan Hasan al-Banna ini memperkuat kesan bahwa jihad itu adalah suatu doktrin perjuangan dengan mempertaruhkan nyawa.

Buku lain yang secara khusus membahas kata ini adalah karya Abuya A.R. Sutan Mansur, seorang tokoh dari Sumatera Barat yang pernah menduduki jabatan sebagai Ketua Umum PP Muhammadiyah tahun 1952. 1957. Menurut ulama besar Indonesia ini, jihad adalah "bekerja sepenuh hati". Di sini ia tidak memakai istilah "berjuang", melainkan "bekerja". Diakuinya bahwa jihad bisa berbentuk perang, tetapi baginya "perintah perang adalah terbatas". Ia berpendapat bahwa jihad dalam keadaan damai itu lebih berat. "Jihad diwaktu damai itu artinya membangun, menegakkan dan menyusun”, katanya.

Kalau kita melihat ayat-ayat jihad yang turun di Makkah, maka kata-kata itu memang mengndung arti umum, yaitu "bersungguh-sungguh dalam melakukan sesuatu”. Untuk bisa bersungguh-sungguh itu seseorang perlu mempersiapkan syarat-syaratnya agar tercapai tujuannya melalui kegiatan itu. Jihad terutama lebih mengarah kepada sumber daya yang terdapat pada manusia sendiri.

\section{Ulu Al-Amr-I}

Istilah ulu al-amr-i oleh ahli al-Quran, Nazwar 
Syamsu, diterjemahkan menjadi functionaries, orang yang mengemban tugas, atau diserahi menjalankan fungsi tertentu dalam suatu organisasi. Sedangkan menurut Muhammad 'Ali, kata ulu al-amr-i berarti orang yang memegang kekuasaan. Pengertian otoritas dan kekuasaan dikaitkan dengan istilah ulu al-amr-i, yaitu seseorang atau mereka yang mengurusi segala urusan umum. Muhammad 'Ali menyebut bahwa alamr atau "urusan" itu bisa bermacam-macam dan dapat ditangkap dengan pengertian "bidang", seperti bidang militer, keduniawian (politik), atau keagamaan.

Di satu pihak, 'Ali menyebut bidang-bidang kehidupan kemasyarakatan yang menimbulkan kekuasaan. Di lain pihak, ia memfokuskan hubungan antara seseorang dengan penguasa. Ulu al-amr-i, adalah pemegng kekuasaan, pemegang komando, pemegang keputusan atas perkara, pemegang otoritas, kepada siapa kaum muslim harus taat, kecuali untuk mendurhakai Allah dan Rasul-Nya. Masalahnya timbul, ketika kaum Muslim dihadapkan kepada penguasa kafir, penguasa yang beragama lain, atau penguasa yang tidak adil.

Para ulama ahli tafsir dan ahli hadits berbeda-beda pendapat tentang ulil amri yang wajib ditaati. Di antara yang disebut adalah: (1) Raja-raja dan kepalakepala pemerintahan yang taat kepada Allah dan RasulNya; (2) Para raja dan ulama yang menjadi sumber rujukan keputusan para raja; (3) Para amir di zaman Rasulullah s.a.w. dan sepeninggal beliau berpindah kepada khalifah, qadi, komandan militer, dan mereka yang meminta anggota masyarakat untuk taat atas dasar kebenaran; (4) Para ahli ijtihad tentang hukum agama atau yang disebut ahl al-halli wa al-aqdli, yaitu mereka yang memiliki otoritas untuk menetapkan hukum; dan (5) Para raja yang benar dan kepala negara yang adil, sedangkan yang zalim tidak ditaati.

\section{BEBERAPA ISTILAH DALAM STUDI- AS SYIYASYAH}

Kejayaan Madinah, dalam tahapan berikutnya telah memberikan inspirasi bagi pengembangan kajian ilmu politik. Beberapa istilah tersebut terutama berkenaan dengan hukum internasional, hukum tata negara dan hukum ekonomi.

\section{Ahkam Ad-Dauliyah (Hukum Internasional)}

Ad-dauliyah merupakan bentuk sifat dari kata addaulah yang berarti negara atau kenegaraan. Dalam bahasa Indonesia Al Ahkan ad-dauliyah disebut juga sebagai hukum antar negara atau hukum internasional.

Hukum internasional terdefinisi sebagai segala bentuk tata aturan atau teori-teori mengenai sistem tata hukum internasional dan hubungan hukum antarbangsa. Toeri hukum Islam kontemporer memperkenalkan konsepsi Al Ahkam ad-Dauliyah al 'ammah, yaitu hukum internasional mengenai masalahmasalah makro; dan Al Ahkam ad-Dauliyah al khassah, yakni hukum internasional mengenai masalah-masalah mikro atau hukum perdata internasional.

Dalam konteks sejarah kenabian, pada masa rasulullah dikenal adanya satu bentuk sistem kekuasaan yang kemudian berkembang menjadi satu sistem kekuasaan khilafah atau kekhalifahan. Dalam konteks ini dunia internasional dibedakan menjadi tiga macam :

$\S$ Dar as-salam yakni negara yang ditegakkan atas dasar dan untuk memperjuangkan berlakunya syariat Islam dalam seluruh bidang kehidupan.

$\S$ Dar al-harb yakni negara non Islam yang kehadirannya mengancam kekuasaan negara-negara Islam serta bermusuhan terhadap warga negaranya yang menganut agama Islam.

$\S$ Dar as-suluh yakni negara yang meskipun non Islam akan tetapi menjalin persahabatan dengan negaranegara islam dan eksistensinya melindungi warga negara yang menganut agama islam.

Hubungan antara dar as-salam, dar altharb dan dar assuluh agak sedikit berbeda. ${ }^{2}$ Perbedaan konsepsi hubungan antara Dar as-salam dan Dar al-harb dipandang sebagai suatu potensi munculnya disharmoni, dimana masing-masing pihak punya kecenderungan perang satu sama lain. ${ }^{3}$

Kekuasaan politik Islam berikutnya mengalami perubahan, tidak hanya mengakui satu sistem khalifah, tetapi telah mengakui keragaman persepsi tentang khilafah. Selain itu juga memberi pengakuan atas otonomi negara-negara bagian keamiran dan 
kesultanan dari Andalusia hingga Asia Tenggara.

Setelah hampir seluruh wilayah Islam di kuasai oleh kekuasaan imperialis bangsa-bangsa Eropa, ide-ide modernisasi yang dibawa kaum imperialis Barat pelan tetapi pasti mempengaruhi pemikiran dan konsepsi politik umat Islam mengenai negara dan dunia internasional secara umum. Kondisi demikian memaksa para negarawan di dunia Islam mengadakan penyesuaian-penyesuaian cara pandang tentang dunia islam dan dunia internasional dalam dominasi ide-ide Barat itu. Konsepsi tentang negara yang tidak lagi terpusat dari postulat perbedaan dan persamaan agama yang dianut, tetapi beralih kepada postulat ideologis yang dipengaruhi oleh paham-paham dunia mengenai demokrasi serta sosialisme.

Namun demikian ada bagian yang dianggap penting terkait dengan konteks kerangka umum hukum antargolongan, bangsa, dan negara-negara yang dianggap mencerminkan pikiran dunia Islam yakni prinsip kedaulatan.

Adanya kebebasan serta kedaulatan bagi tiap-tiap negara untuk mengatur urusan rumah tangganya sendiri tanpa intervensi atau campur tangan dari pihak manapun yang berada diluar batas-batas wilayah kekuasaannya dan mempertahankan diri dari ancaman instabilitas dari dalam maupun dari luar, serta secara mandiri dapat melakukan kerja sama alih tehnologi dan ilmu pengetahuan demikian halnya dengan aktivitas perekonomian dan perdagangan atas dasar kemaslahatan menurut ukuran-ukuran yang dapat dibenarkan oleh syara' (hukum Islam).

Dalam konteks umat, seluruh bangsa yang menganut agama Islam di berbagai negara adalah bersaudara. Sedangkan dalam konteks global, setiap manusia di seluruh dunia memiliki hak dan tanggung jawab yang asasi untuk meningkatkan taraf hidup dan untuk mengabdikan dirinya bagi bangsa, negara, dan agamanya dalam satu taman dunia yang utuh dan padu.

\section{AL AHKAM AL-IQTISADIYAH WA AL MA-LIYAH (HUKUM EKONOMI)}

Secara umum terminologi Al ahkam al iqtisadiyah wa al ma-liyah digunakan untuk menunjuk kepada pengertian hukum atau tatanan yang mengatur sistem ekonomi dan keuangan berkenaan dengan upaya manusia mencukupi kebutuhan, meningkatkan taraf hidup, dan mewujudkan kesejahteraan, baik secara individu maupun secara kolektif.

Pada periode Mekkah umat Islam telah mengenal aktivitas ekonomi dalam bentuknya yang masih sederhana, seperti mengembala binatang ternak, membuat alat rumah tangga atau perang, menjadi buruh kasar, atu budak. Sementara golongan menengah ke atas, berdagang. Mereka mengenal aktivitas kewirausahaan. Nabi Muhammad SAW memberikan dukungan moril cukup kuat kepada mereka yang berusaha dalam sektor pertanian, meskipun akumulasi kekayaan beberapa sahabat muncul dalam sektor perdagangan.

Kritik-kritik tajam Nabi SAW dalam sektor perdagangan (seperti masalah riba, penumpukan kekayaan atau monopoli, dan lain-lain) tampak berkaitan erat dengan kuatnya kaum Yahudi Madinah sebagai pemeran penting di lapangan perdagangan. Sementara itu, kaum petani kalangan Muhajirin dan Anshor sering kali dirugikan dengan fluktuasi harga yang diciptakan oleh orang-orang tertentu dalam sistem "pasar".

Revolusi sosial pasca Hijrah ditandai dengan adanya pengaturan yang ketat mellui instruksi Nabi mengakibatkan kegiatan ekonomi tidak lagi sederhana. Kota Mekah ketika itu merupakan pusat perdagangan, sebagai penghubung jalur perekonomian Samudera Hindia dengan Laut Tengah. ${ }^{4}$ Munculnya mazhabmazhab baru membuat lebih terorganisirnya lagi aktivitas ekonomi, hingga abad ke-19, karya-karya mengenai masalah ekonomi masih menggunakan

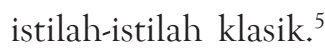

Pengkajian tema-tema ekonomi berikutnya mengalami perkembangan baru, terutama sejak meluasnya pengaruh pemikiran Barat modern yang telah berhasil merumuskan teori-teori ilmu ekonomi secara sistematis. Perkembangan ini ditandai dengan munculnya istilah-istilah seperti al-mu'amalah al-hadisah (hukum ekonomi modern), al-Bunuk al-islamiyah (bank 
Islam), dan niwanizam iqtisadi 'alami jadid (sekitar sistem ekonomi dunia modern).

\section{AL AHKAM AL-MADANIYAH (HUKUM PRIVAT)}

Disebut juga dengan hukum privat atau hukum perdata (hukum sipil), yang mengatur segala hal dalam hubungan perorangan, mencakup persoalan hukum keluarga, aturan mendirikan usaha atau melakukan transaksi, aturan pengelolaan keuangan, barang dan jasa, aturan tentang hak milik, aturan sekitar wakaf, wasiat serta hibah, dan persoalan-persoalan sengketa hubungan antara kepentingan perorangan. ${ }^{6}$

Dalam kajian literatur Islam al ahkam al madaniyah atau al qanun al madani sepertinya tidak bisa dilepaskan dari as-syari'ah al Islamiyah meskipun secara terminologi dapat dibedakan. Dikatakan oleh alMustasyar Abdus Sattar Adam, seorang ahli fiqh Mesir, dalam tulisannya asy-Syariah al-Islamiyyah wa alQanun al-Madani al-Misri (Syariat Islam dan Hukum sipil Mesir) bahwa asy-Syariah menurut arti kebahasaan adalah sumber air yang oleh manusia- demikian pula segala jenis binatang-dijadikan sebagai kses bahan mineral.

Secara terminologis syari'ah adalah hukum atau tata aturan yang berisikan kumpulan ajaran Allah SWT untuk ditaati oleh hamba-hamba-Nya berkenaan dengan hubungan antar manusia dengan Tuhannya dan hubungan antar sesama manusia, yang hanya berubah apabila ada ijtihad oleh para ulama dengan disesuaikan terhadap perkembangan zaman. Sedangkan Al-qanun dipahami sebagai kumpulan tata aturan yang mengatur pelbagai ragam kepentingan masyarakat dengan ciri khas memiliki kepastian hukum melalui alat kekuasaan negara. Al-qanun yang lindungi publik muncul dalam perundang-undangan yang dikenal dengan hukum pidana (al Qanun Al-Jina'i), hukum tata usaha negara (al Qanun Al-Idari), dan hukum internasional mengenai perang serta perdamaian (al Qanun ad-Dauli al-Amm).

Hukum perdata (sipil atau privat) sebagaimana yang diperkenalkan oleh Barat ke negeri-negeri Islam pada mulanya masih dalam bentuk asli, pada masa kolonial terutama ketika berbahasa Perancis. Karena hukum tersebut diberlakukan terhadap masyarakat yang umumnya lebih menguasai bahasa Arab, kenudian dialihbahasakan kedalam bahasa Arab. Setelah hukum ini dipahami oleh masyarakat yang kepadanya diberlakukan hukum Perancis, selanjutnya terjadi berbagai kontroversi terhadap bagian-bagian materi hukum yang dirasakan bertentangan dengan keyakinan dan kelaziman hukum masyarakat. Lama kelamaan undang-undang itu mengalami beberapa kali perubahan dengan mentransfer perundang-undangan hukum perdata negara lain, baik dari Italia maupun Jerman dengan memperhatikan semangat hukum Islam yang telah menjiwai masyarakat dimana hukum itu hendak diberlakukan. Setelah negeri-negeri Islam menjadi merdeka, kerangka sistem hukum Barat masih tetap mewarnai struktur hukum negara masing-masing, meskipun bahan bakunya tetap banyak diambildari materi hukum yang dikenal dalam mazhab-mazhab fikih Islam klasik.

Contoh yang dapat dianggap realistis untuk melihat bentuk al ahkam al-madaniyyah produk sejarah di negara-negara Islam adalah Undang-undang Hukum Perdata Mesir yangdikeluarkan pada 16 Juli 1948 dan diberlakukan pada 15 Oktober 1949. Undang-undang tersebut digali dari empat sumber :

$\varnothing$ Undang-undang Hukum Perdata Mesir yang dikeluarkan tahun 1876 dan tahun 1883 yang berasal dari undang-undang Perancis.

$\varnothing$ Undang-undang lain yang pernah diberlakukan pada beberapa negara di dunia islam, seperti Maroko, Tunisia, Libanon, dan lain-lain. Undangundang itu brasal dari negara Italia, Spanyol, Portugal, Belanda, dan Jerman.

$\varnothing$ Keputusan-keputusan pengadilan Mesir sendiri sejak diberlakukannya undang-undang Perancis.

$\varnothing$ Syariah Islamiyah

Meskipun undang-undang hukum perdata Mesir digali dari berbagai sumber, namun hukum itu tetap mencerminkan keterkaitannya dengan nash-nash syara' alam hampir semua segi. Apabila tidak ditemukan nash-nash syara', maka hakim menetapkan hukum berdasarkan 'urf (kebiasaan), atau diterapkan kaidah- 
kaidah Usul yang lain sebagaimana dikenal dalam teori hukum Islam. Bila tidak juga ditemukan pemecahannya, barulah hakim mempertimbangkan prinsip-prinsip kedilan yang dikenal secara universal dari berbagai teori ilmu hukum Barat atau hukum wad'i. Dengan demikian, hukum perdata di Mesir pada dasarnya dapat disebut dengan "Hukum Perdata Islam”.

\section{KESIMPULAN}

Beberapa ajaran etika yang menjadi landasan bagi terwujudnya sistem tatanan hukum antara lain "etika keadilan" yang mengajarkan tentang :

- Tegaknya porsi yang seimbang antara beban tanggung jawab yang dipikul dengan imbalan prestasi yang diterima.

- Terpenuhinya kadar yang sama antara kualifikasi dan kuantifikasi ukuran (sukatan atau timbangan) dalam setiap curahan tenaga, pikiran, barang serta jasa yang sama.

- Memberikan pilihan-pilihan modus "jalan tengah" dalam setiap mengintegrasikan konflik kepentingan.

Etika selanjutnya adalah "etika maslahat", memberikan alternatif-altrnatif ihsan (kebajikan) terhadap setiap objek hukum, sehingga barang dan jasa sebagai obyek perdata seyogyanya selain memiliki fungsi ekonomis juga hendaknya memiliki fungsi sosial. Sedangkan sebutan istilah al-ahkam al madaniyah memberikan suatu kesan serta isyarat bahwa Islam menginginkan sistem hukum yang etis bagi masyarakat beradab. Oleh karena itulah al ahkam al madaniyah mesti dinamis, sehingga selalu aktual.

\section{CATATAN AKHIR}

Ayat-ayat tersebut menunjukkan bahwa al-Quran dapat dijadikan sumber sejarah karena informasinya terbukti dalam kenyataan historis.

2 Dar as-salam dengan Dar as-suluh cenderung saling menghormati dan ada hubungan kerja sama sementara antara Dar as-salam dengan Dar al-harb seringkali terlihat adanya potensi konflik baik perang terbuka maupun konflik laten secara kultural.

3 Bedanya, jika dalam islam ada konsepsi "jihad" tidak berarti membantai dan memusnahkan akan tetapi lebih kepada penaklukan sehingga segala fasilitas umum adalah harus dilindungi.

4 Suq al Madinah sebagai pasar rekayasa ditujukan untuk menyaingi pasar Qainuqa yang dikuasai oleh Yahudi. Timbul lembaga keuangan seperti amil zakat dan sbagainya pada masa nabi dan sahabat (diwan (badan atau lembaga) periode Umar bin Khatab, dan baitulmal periode Dinasti Umayyah, menunjukan semakin terorganisirnya perekonomian meskipun memang masih sangat sederhana dan bersifat sementara.

5 Al-kharaj (hukum pajak) karya Abu Yusuf al-Qadi, at-Tabassur bi atTijarah (pengkajian tentang perdagangan) karya al-Jahiz Abu Usman bin Bahar, dan lain sebagainya.

6 Ihwal hukum yang dicakup oleh al ahkam al-madaniyyah sebelumnya telah dikenal dengan istilah figh al-mu'amalah (hukum perdata islam), namun figh al-mu'amalah lebih murni bersifat pemikiran daripada al ahkam al-madaniyyah yang telah masuk atau merupakan bagian dalam kerangka hukum positif.

\section{REFERENSI}

Al-Qur'an dan Terjemahnya, Departemen Agama RI, Jakarta, 1978/ 1979.

Ahmad, Zainal Abidin, Membentuk Negara Islam, Jakarta, 1956. , Piagam Nabi Muhammad SAW Konstitusi Negara Tertulis Yang Pertama di Dunia, Bulan Bintang, Jakarta, 1973.

Ali, Syed Ameer, Api Islam, Sejarah dan Cita-Cita Islam Dengan Riwayat Hidup Nabi Muhammad SAW, Bulan Bintang, Jakarta, 1978

Budiardjo, Miriam, Dasar-Dasar IImu Politik, PT Gramedia, Jakarta, 1989.

Galwash, Ahmad A., The Religion of Islam, Vol. I, Cairo, 1940.

Hart, Michael H., Seratus Tokoh Yang Paling Berpengaruh Dalam Sejarah, Pustaka Jaya, Jakarta, 1997

Al-Ghazali, Abu Hamid, Ihya' 'Ulum al-Din, Dar al-Fikr, Bairut, 1975

Hasan, Ibrahim Hasan, Tarikh al-Islam, Jilid I, Maktabat Nahdhat alMishriyyat, Kairo,1979.

Kerk, George E., A Short History to the Middle East, Public Affairs Press, Washington, 1949.

Khadduri, Madjid, War and Peace in the Law of Islam, The John's Hopkins Press, Baltimore, 1955.

Khalid, Muhammad, Khatam al-Nabiyyin, al-Qahirat,1955.

Mufrodi, Ali, Islam di Kawasan Kebudayaan Arab, Logos Wacana IImu, Jakarta, 1997

Pulungan, J. Suyuthi, Prinsip-prinsip Pemerintahan Dalam Piagam Madinah Ditinjau dari Pandangan Al-Quran, PT RajaGrafindo Persada, Jakarta, 1996.

Rahardjo, M. Dawam, Ensiklopedi Al-Qur'an Tafsir Sosial Berdasarkan Konsep-konsep Kunci, Paramadina, Jakarta, t.th.

Syarif, Ahmad Ibrahim, Daulat al-Rasul fi al-Madinat, Dar al-Bayan, Kuwait, 1972.

Zallum, Abdul Qadim, Pemikiran Politik Islam, Izzah, Bangil, 2001 